\title{
Potency of mycotoxin binders on MDA level, expressions of caspase 9 and caspase 3 in the uterus of mice exposed to zearalenone
}

\author{
A. Samik and E. Safitri* \\ Department of Reproduction Veteriner, Faculty of Veterinary Medicine, Universitas Airlangga, Surabaya, Indonesia \\ *Correspondence Author: rma_fispro@yahoo.com
}

(Received January 16, 2017; Accepted February 22, 2017)

\begin{abstract}
This study examined effect of mycotoxin binder administered to female mice exposed to zearalenon on apoptosis incidence by observe at MDA, Caspase 9 and 3 levels in mice uterus. Negative control group (K-) was not exposed to zearalenon and without the administration of mycotoxin binders, positive control group $(\mathrm{K}+)$ exposed to zearalenon of $0.1 \mathrm{mg} / \mathrm{head} / \mathrm{day}$ and without the provision of mycotoxin binders; and treatment groups (P1, P2, P3) were exposed to zearalenon $0.1 \mathrm{mg} / \mathrm{head} / \mathrm{day}$ by providing mycotoxin binders each $0.5 ; 1 ; 2 \mathrm{mg} /$ head/day. Zearalenon and mycotoxinbinders administration was conducted for 10 days. Results on MDA level were as follows $15.48 \pm 0.50(\mathrm{~K}-), 45.59 \pm 0.50(\mathrm{~K}+), 34.92 \pm 3.38(\mathrm{P} 1), 27.72 \pm 1.25$ and $23.89 \pm 3.74$. Caspase 9 levels showed the following results: $0.3 \pm 0.60(\mathrm{~K}), 8.3 \pm 0.90(\mathrm{~K}+), 3.6 \pm 0.41(\mathrm{P} 1), 3.3 \pm 0.34(\mathrm{P} 2)$ and $2.8 \pm 0.28(\mathrm{P} 3)$, while the levels of Caspase3 were as follows: $3.35 \pm 0.44(\mathrm{~K}-), 12.5 \pm 0.66(\mathrm{~K}+), 3.6 \pm 0.41(\mathrm{P} 1), 4.80 \pm$ 0.43 (P2) and $3.85 \pm 0.50(\mathrm{P} 3)$. In conclusion, mycotoxin binders may lower malondialdehyde (MDA) level and the expression of caspase 9 and caspase 3 in the uterus of mice exposed to zearalenon.
\end{abstract}

Keywords: Zearalenone, mycotoxin binders, MDA level, caspase 9, caspase 3 Available online at http://www.vetmedmosul.org/ijvs

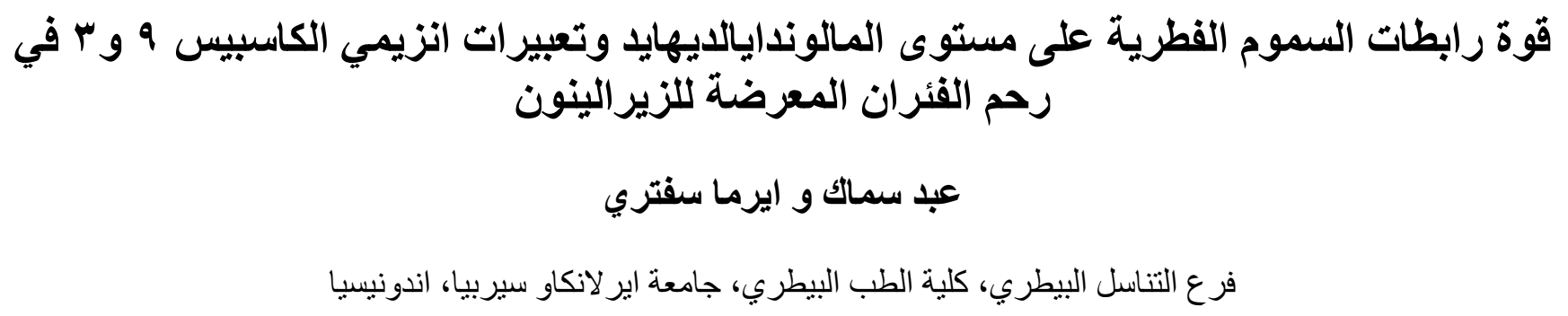

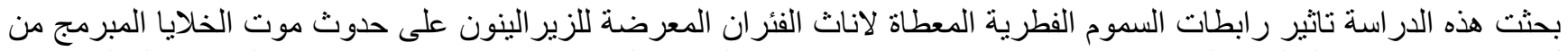

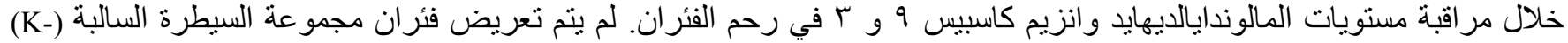

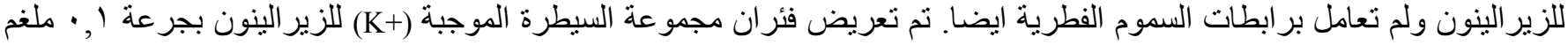

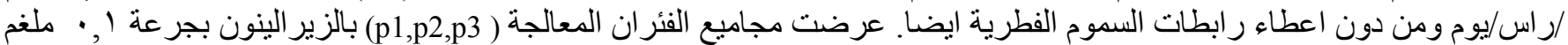

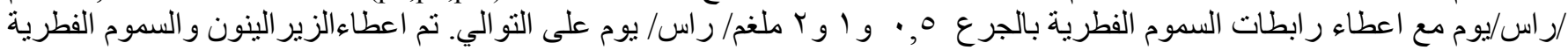

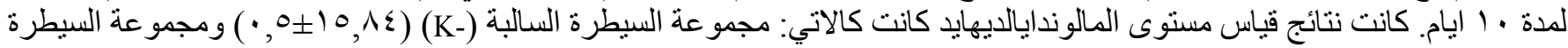

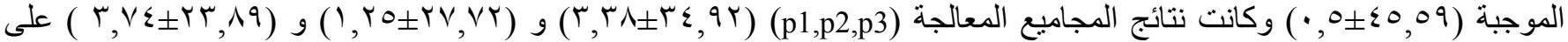

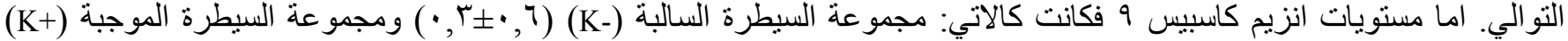

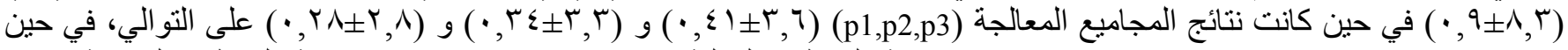

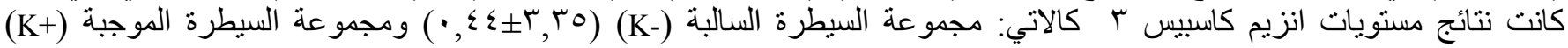




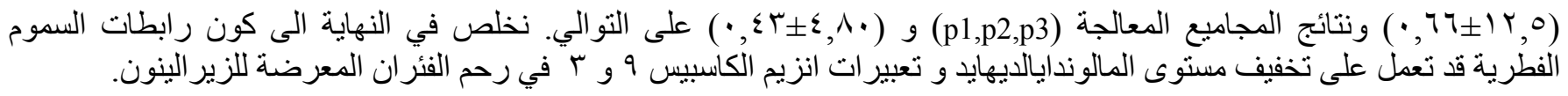

\section{Introduction}

Feed composed of a single or a mixture of food ingredients, whether processed or unprocessed, which is given for animal's survival, production, and breed. Corn is one of the agricultural commodities very important for humans and livestock. Corn is a high-energy feed ingredients, but contain relatively low protein compared to other grain feed. Corn contains a protein content of about 8.6 to $9.0 \%$. Corn protein is not fermented or degraded by rumen microorganisms, but digested and absorbed in small intestine.

The fungus Fusariumgraminearum is a pathogenic flora that may attack corn and capable of producing zearalenon (ZEN). ZEN may increase estrogen levels that trigger estrus cycle disorders (1). The ZEN is a natural estrogen mycotoxins that may induce changes in metabolic profile and organ cell activity of the uterus, liver, spinal cord, brain, mammary gland, and intestinal epithelial cells (2).

The objective of this study was to demonstrate the potential of mycotoxin binders on MDA level, cytochrome c, the expression of caspase 9, caspase 3 in female mice exposed to ZEN. The benefits of this study was to provide knowledge in the field of veterinary medicine about mycotoxin binders in preventing potential negative effects on livestock reproduction caused by ZEN. In the field of animal health, it is expected that this study on the potential of mycotoxin binders may be solution to address reproductive health problems posed by $\mathrm{ZEN}$ and can improve livestock productivity through control of mycotoxins from the feed.

\section{Materials and methods}

\section{Treatment for experimental animals}

This study used 20 female mice (Musmusculus) with 4 mice in each groups as experimental animals with the following criteria: healthy, aged 8 to 9 weeks with body weight ranging from 20 to 40 grams and sexually mature. This study was an experimental laboratory study with five treatments as follows: negative control $(\mathrm{K}-)$ without being administered with zearalenon (Biotech Co., Ltd., hangzhou, Zhejiang, China) and mycotoxin binders (Impextraco Ltd, Bangkok, Thailand), positive control $(\mathrm{K}+)$ given with zearalenon dose of $0.1 \mathrm{mg} / \mathrm{head} /$ day without mycotoxin binders (dilution of zearalenon with aquadest), treatment 1 (P1) given with zearalenon in a dose of $0.1 \mathrm{mg} / \mathrm{head} /$ day with mycotoxin binders of $0.5 \mathrm{mg} / \mathrm{head} / \mathrm{day}$, treatment 2 (P2) was given with zearalenon in a dose of 0.1 $\mathrm{mg} /$ head/day with addition of mycotoxin binders 1 $\mathrm{mg} /$ head/day, and treatment 3 (P3) receibed zearalenon in a dose of $0.1 \mathrm{mg} / \mathrm{head} /$ day with administration of mycotoxin binders $2 \mathrm{mg} / \mathrm{head} /$ day. Zearalenon and mycotoxin binders administration was done orally for ten days. Variables observed in this study were MDA level and the expression of caspase 9 and caspase 3 .

\section{Animal surgical procedures and sampling}

Surgery was performed on day 15 after (Prior to treatment the mice are adapted for 4 days, giving zearalenone and mycotoxin binders for 10 days starting day 5 to day 14 and day 15 surgery) carrying out cervical os dislocation. Disinfection was done with $70 \%$ alcohol, then surgery was done quickly to remove the uterus and stored in buoin solution with composition of $75 \mathrm{ml}$ saturated picric acid, $25 \mathrm{ml}$ of $40 \%$ formalin and $5 \mathrm{ml}$ glacial acetic acid for making immunohistochemical preparations (3).

\section{MDA measurement procedure}

MDA examination procedure is initiated by weighing 0.3 gram uterus added with $4.5 \mathrm{ml}$ of cold PBS and then manual crushed, and then centrifuged at $320 \times \mathrm{g}$ for 15 minutes. The supernatant was taken as many as $4 \mathrm{ml}$, and then added with $1 \mathrm{ml}$ TCA $15 \%$ and followed by addition of $1 \mathrm{ml}$ of $0.37 \%$ TBA solution in $0.25 \mathrm{~N} \mathrm{HCl}$. Once mixed evenly, it was heated in a water bath with a temperature of $80^{\circ} \mathrm{C}$ for 15 minutes, cooled at room temperature for 60 minutes, then centrifuged at $320 \times \mathrm{g}$ for 15 minutes. Thereafter, the absorbance of uterus MDA supernatant can be measured using a spectrophotometer $(\lambda=532 \mathrm{~nm})$ and calculated using standard curve regression line of MDA solution (4).

\section{Identification of caspase 9 and caspase 3 expression by immunohistochemistry test}

Uterus preparations, which had been made on object glass, were dipped in xylol twice, alcohol-rise $(100 \%, 90 \%$, $80 \%, 70 \%$ and $30 \%$ ) and distilled water, respectively. Furthermore, preparations were washed in PBS in $\mathrm{pH} 7.4$ for 3 times each for 5 minutes and soaked in 3\% hydrogen peroxide (H2O2) for 5 - 10 minutes, soaked in 1\% BSA in PBS for 10 - 30 minutes at room temperature, added with Biotin labeled anti-caspase 9 IgG primary antibody for 1 hour at room temperature and washed in PBS $\mathrm{pH} 7.4$ for 3 $\times 5$ minutes. Then, Streptavidin-Horse Radish Peroxidase (SA-HRP) was added for $30 \times 60$ minutes in room temperature, washed in PBS $\mathrm{pH} 7.4$ for $3 \times 5$ minutes, added with 3.3-Diaminbenzidine tetrahydrochloridechromogen (DAB) for 10 - 20 minutes, 
washed with distilled water for $3 \times 5$ minutes at room temperature and then added with counterstain (Methylen blue/Methylen green) for 3 minutes. Mounting was then carried out with entellan. Observations were made with Olympus ${ }^{\circledR}$ CX-41 microscope in magnification 40,100 , 400,1000 times. Determination of the amount of expression of caspase 9 and caspase 3 can be seen from the number of brownish discoloration on the uterine organs compared to controls (5).

\section{Data analysis}

MDA content data were tested for homogeneity with the Kolmogorov-Smirnov test. If the data were homogeneous, the test was followed with parametric analysis using oneway ANOVA and if significantly different $(\mathrm{P}<0.05)$ it was followed by Fisher's LSD test. If the data was not homogeneous the analysis used non-parametric KruskalWallis test and if it was significantly different $(\mathrm{P}<0.05)$ it was followed by Mann-Whitney test. Data on caspase 9 and 3 expression were tested with nonparametric comparative Kruskal-Wallis test followed by Mann-Whitney test.

\section{Results}

The results of calculations and scoring of MDA, Caspase 9 and Caspase 3 in uterine cells of mice exposed to zearalenon can be seen in Table 1 .

Table 1 shows that MDA level, the expression of caspase 9 and 3 decreased. MDA levels in the treatment groups $\mathrm{K}+\left(45.59^{\mathrm{d}} \pm 0.50\right)$ was significantly different from all treatments $\mathrm{P} 1 \quad\left(34.92^{\mathrm{c}} \pm 3.38\right), \mathrm{P} 2 \quad\left(27.72^{\mathrm{b}} \pm 1.25\right), \mathrm{P} 3$ $\left(23.89^{\mathrm{b}} \pm 3.74\right)$ and $\mathrm{K}-\left(15.48^{\mathrm{a}} \pm 0.50\right)$. Caspase 9 expression was decreased in P1 $\left(3.6^{\mathrm{b}} \pm 0.41\right), \mathrm{P} 2\left(3.3^{\mathrm{b}} \pm 0.34\right)$ and $\mathrm{P} 3$ $\left(2.8^{\mathrm{b}} \pm 0.28\right)$ were significantly different from $\mathrm{K}+$ $\left(8.3^{\mathrm{c}} \pm 0.90\right)$, while $\mathrm{K}-\left(0.3^{\mathrm{a}} \pm 0.60\right)$ was significantly different from all treatments. Caspase 3 expression was decreased in P1 $\left(7.70^{\mathrm{c}} \pm 0.73\right), \mathrm{P} 2\left(4.80^{\mathrm{d}} \pm 0.43\right), \mathrm{P} 3\left(3.85^{\mathrm{a}} \pm 0.50\right)$ and $\mathrm{K}-$ $\left(3.35^{\mathrm{a}} \pm 0.44\right)$ were significantly different from $\mathrm{K}+$ $\left(12.5^{\mathrm{b}} \pm 0.66\right)$, while P3 $\left(3.85^{\mathrm{a}} \pm 0.50\right)$ and $\mathrm{K}-\left(3.35^{\mathrm{a}} \pm 0.44\right)$ were not significantly different.

\section{Discussion}

Results of statistical analysis showed that zearalenon was able to modulate or trigger ROS. It is characterized by the appearance of MDA in treatment group receiving zearalenon added with mycotoxin binders and negative control $(\mathrm{K}-)$ in the uterus. Effects of mycotoxin binders has been prove to become antagonist against zearalenon as indicated by decreased MDA levels.

Free radicals can be produced by a variety of physiological processes and has an important role as a signaling molecule such as electron transport. In physiological conditions, free radicals may be mitigated efficiently by antioxidants to prevent cell damage. In pathological conditions, excessive production of free radicals that followed the decrease in antioxidants and can not dampen the action of free radicals, resulting in oxidative stress (6). Oxidative stress can be harmful because it can damage macromolecules in cells such as carbohydrates, proteins and DNA. Damaged macromolecules may then lead to cell death (7).

Table 1: MDA, Caspase 9 and Caspase 3 Levels in Mice Uterus

\begin{tabular}{lccc}
\hline Treatment & $\begin{array}{c}\text { MDA level } \\
\pm \text { sd }\end{array}$ & $\begin{array}{c}\text { Caspase 9 } \\
\text { expression } \\
\pm \text { sd }\end{array}$ & $\begin{array}{c}\text { Caspase 3 } \\
\text { expresson } \\
\pm \text { sd }\end{array}$ \\
\hline $\mathrm{K}-$ & $15.48^{\mathrm{a}} \pm 0.50$ & $0.3^{\mathrm{a}} \pm 0.60$ & $3.35^{\mathrm{a}} \pm 0.44$ \\
$\mathrm{~K}+$ & $45.59^{\mathrm{d}} \pm 0.50$ & $8.3^{\mathrm{c}} \pm 0.90$ & $12.5^{\mathrm{b}} \pm 0.66$ \\
$\mathrm{P} 1$ & $34.92^{\mathrm{c}} \pm 3.38$ & $3.6^{\mathrm{b}} \pm 0.41$ & $7.70^{\mathrm{c}} \pm 0.73$ \\
$\mathrm{P} 2$ & $27.72^{\mathrm{b}} \pm 1.25$ & $3.3^{\mathrm{b}} \pm 0.34$ & $4.80^{\mathrm{d}} \pm 0.43$ \\
$\mathrm{P} 3$ & $23.89^{\mathrm{b}} \pm 3.74$ & $2.8^{\mathrm{b}} \pm 0.28$ & $3.85^{\mathrm{a}} \pm 0.50$ \\
\hline
\end{tabular}

Different superscripts in the same column show significant differences among treatments $(\mathrm{P}<0.05)$, Description: $\mathrm{K}-\mathrm{=}$ group of mice not exposed to zearalenon and without the provision of mycotoxin binders; $\mathrm{K}+=$ group of mice exposed to zearalenonof $0.1 \mathrm{mg} / \mathrm{head} /$ day and without the provision of mycotoxin binders; P1, P2, P3 = zearalenon group of mice exposed to $0.1 \mathrm{mg} / \mathrm{head} /$ day with administration of mycotoxin binders $0.5 ; 1 ; 2 \mathrm{mg} / \mathrm{head} /$ day. MDA: Malondialdehyde.

Zearalenon lipophilic nature makes it able penetrate cell membranes and interact with the mitochondria. During interaction phase with mitochondria zearalenon inhibits mitochondrial respiratory pathway, causing ATP depletion, thereby increasing the amount of reactive oxygen species (ROS) that may damage mitochondrial DNA or insert themselves in replicating process, or directly caused mitochondrial permeability transition (MPT) to make a hole in MPT pore that is located on the inside of the membrane. The opening of this MPT pore is the onset of cell death, often called the process of apoptosis $(8,9)$.

Mycotoxin binders containing aluminosilicate compounds have proven to be the most effective to bind mycotoxinszearalenon. Action mechanism of mycotoxin binders is by eliminating methyl group on zearalenon chemical structure (10). Silicate structure consists of neosilicate, sorosilicate, inosilicate, siclosilicate, filosilicate, and tectosilicate. The structure will be transformed into Hydrated Sodium Calcium Aluminosilicate which is easily metabolized by the body. Mycotoxin binders are also equipped with a decontaminant material useful in improving animals' condition and 
eliminating mycotoxins negative effects during exposure $(11,12)$.

Research $(7,8)$ concluded that the molecular toxic effects caused by zearalenon may cause oxidative stress and induces apoptosis intrinsic pathway in mitochondria. In many apoptoyic process, especially in the liver and gonads, excessive production of ROS is associated with the apoptosis pathways of mitochondria. A study by (13) showed that ROS resulting from zearalenon exposure and mitochondrial changes is due to increased ROS levels. This indicates that zearalenon induces oxidative stress that causes apoptosis.

The existence of free radicals may break DNA chains or cause changes in DNA nucleotides composition. DNA damage activates p-53 and the latter's activation may trigger Bax activity, suppressing $\mathrm{Bcl}-2$ in mitochondrial membrane, resulting in mitochondrial membrane permeability changes, leading to the release of cytochrome $\mathrm{C}$ to cytosol. Cytochrome $\mathrm{C}$ activates Apaf-1 and subsequently activates caspase cascade and activates the DNA-se, and then damages the DNA so that the cells undergo apoptosis (14).

There are two important components that cause cytochrome $\mathrm{C}$ release, the mitochondria permeability transition pore (MPTP) and the proapoptotic protein Bax. The opening of MPTP is influenced by several factors, such as calcium accumulation, oxidants and low mitochondrial transmembrane potential. The merging of Bax with MPTP may form a pore in mitochondrial outer membrane, so as to facilitate the release of determinants of apoptosis, the cytochrome C, AIF and Smac/Diablo, which will then be translocated into the nucleus and causes of DNA fragmentation $(8,9)$.

Caspase 9 expression of in K- group was significantly different from all treatments. So was K+. However, among groups P1, P2 and P3 there was no significant difference. Meanwhile, between treatments P1, P2 and P3 there was significant difference.

A study by (15) mentions that zearalenon may initiate apoptotic process. Apoptotic molecular process occurs through intrinsic pathway in mitochondria with caspase 9 as the initiator and caspase 3 as the executor. Zearalenon is designated as a cytotoxic agent that triggers hyperestrogenisme in reproductive system as it is able to induce massive apoptosis.

Hyperestrogenisme would disturb Transmisible Permeability Pore (PTP) consistency on mitochondrial membrane. PTP damage may result in megachannel activation that will affect electron transport failure. Active megachannel may also be followed by the influx of extracellular $\mathrm{Ca} 2+$ ion and accumulates with intracellular $\mathrm{Ca} 2+$ ions containing in the mitochondria and endoplasmic reticulum. High $\mathrm{Ca} 2+$ level which may increase $\mathrm{Bax}$ expression and decrease Bcl-2 (2).

Caspase 9, which acts as apoptosis initiator, may be dimerized, triggering a feedback by inhibiting $\mathrm{Bcl}-2$ release of and binding procaspase 3 to activate caspase3. Caspase3, which act as executor, mayassits cytoplasmic endonucleases and proteases activation that may fragment nuclear DNA and degrade cytosol protein. The final result in fragmentation process is the formation of apoptotic bodies containing intracellular organelles and expresses phosphatidylserine that may trigger phagocytosis $(16,17)$. The expression of caspase 3 in $\mathrm{K}$ - group was significantly different from that in other treatment groups. However, group $\mathrm{K}+$ was significantly different from groups $\mathrm{P} 1$ and $\mathrm{P} 2$, but not significantly different from $\mathrm{P} 3$.

Apoptotic molecular process occurs through the intrinsic pathway in the mitochondria and caspase 3 as executor. Zearalenon is expressed as cytotoxic agents in reproductive system as it can induce massive apoptosis. A study by (18) also explains that zearalenon exposure may lead to cell death, largely by apoptosis and in part by necrosis fraction. Zearalenon exposure leads to loss of Mitochondrial Membrane Potential (MMP), mitochondrial change in the amount of protein $\mathrm{Bcl}-2$ and $\mathrm{Bax}$, and cytoplasm cytochrome $\mathrm{c}$ release. Cytochrome $\mathrm{c}$ release may trigger procaspase 9 and Apaf-1 merges into complex apoptosome. It is this apoptosome that will modulate the formation of the executioner caspases, one of which is caspase3 (19).

Caspase3, that acts as executor, may help endonucleases activation and cytoplasmic proteases that may lead to nuclear DNA fragmentation and degrade cytosol protein. Final result in fragmentation process is the formation of apoptotic bodies containing intracellular organelles and expresses phosphatidylserine that will trigger phagocytosis $(16,17)$

In conclusion, in this study, mycotoxin binders may decrease malondialdehyde (MDA) level, caspase 9 and caspase3 expressions in mice (Musmusculus) uterus exposed to zearalenon. Mycotoxin binders can be given simultaneously with the feed to prevent the effects that arise when cattle consume feed contaminated with Fusariumgrameniarum fungi that produces zearalenon. Storage of animal feed should be reliable to avoid mold growth that is harmful to livestock.

\section{Acknowledgement}

The study was supported by funding from the Directorate General of Higher Education (DIKTI) 2015. The National Education Ministry. Republic of Indonesia. 


\section{References}

1. Nikov GN, Hopkins NE, Boue S, Alworth WL. Interactions of dietary estrogens with human estrogen receptors and the effect on estrogen receptor-estrogen response element complex formation. Environ Health Perspect. 2000;108:867-872.

2. Maresca M, Fantini J. Some food-associated mycotoxins as potential risk factors in humans predisposed to chronic intestinal inflammatory diseases. Toxicon. 2010;56:282-294.

3. Sinuhaji I, Siregar B, dan Lisnawati. Ekspresi p16 $6^{\mathrm{INK} 4 \mathrm{~A}}$ pada Karsinoma Serviks Usia Muda. Departemen Patologi Anatomik. Fakultas Kedokteran Universitas Indonesia. Jakarta. J Indon Med Assoc. 2013;63:1.

4. Conti M, Moran PC, Levillain P. Improved fluorimetric determination of malondialdehyde. Clin Chem. 1991;37:1273-1275.

5. Crosby K, Simendinger J, Grange C, Ferrante M, Bernier T, Stanen C. Immunohistochemistry protocol for paraffin-embedded tissue sectionadvertisement. Cell Signaling Technoogy. JoVE PubMed-indexed video J. 2016.

6. Sathyasaikumar KVI, Swapna PVB, Reddy ChRK, Murthy AD, Gupta B, Senthilkumaran PR. Fulminant hepatic failure in rats induces oxidative stress differentially in cerebral cortex, cerebellum, and pons medulla. Neurochem Res. 2007;32:517-524.

7. Halliwell B, Gutteridge JMC. Free Radicals in Biology and Medicine. $1^{\text {st }}$. Oxford: Oxford University Press; 1999.

8. Albano E. Oxidative mechanisms in the pathogenesis of alcoholic liver disease. Mol Aspect Med. 2008;29:9-16.

9. Holme JA, Gorria M, Volker MA, Øvrebø S, Solhaug A, Tekpli X, Nina EL, Huc L, Fardel O, Lagadic-Gossmann D. Different mechanisms involved in apoptosis following exposure to benzo[a]pyrene in F258 and hepalc1c7 cells. Chem Biol Interact. 2007; 167:41-55.

10. Doll S, Danicke S, Valenta H, Flachowsky G. In vitro studies on the evaluation of mycotoxin detoxifying agents for their efficacy on deoxynivalenol and zearalenone. Arch Anim Nutr. 2004;58:311-324.
11. Bingham AK, Phillips TD, Bauer JE. Potential for dietary protection against the effects of aflatoxins in animals. JAVMA. 2003;222:591596.

12. Whitlow LW, Hagler-Jr WM. Mycotoxins in feeds. Feedstuffs. 2005;77(No. 38):69-79.

13. Bouaziz C, el-Dein OS, el-Golli E, Abid-Essefi S, Brenner C, Lemaire C, Bacha H. Different apoptotic pathways induced by zearalenone, T2 toxin and ochratoxin A in human hepatoma cells. J Toxicol. 2008;254;19-28.

14. Kouadio JH, Mobio TA, Baudrimont I, Moukha S, Dano SD, Creppy EE. Comparative study of cytotoxicity and oxidative stress induced by deoxynivalenol, zearalenone or fumonisin B1 in human intestinal cell line Caco-2. Toxicol. 2005;213:56-65.

15. Zhu L, Yuan H, Guo C, Lu Y, Deng S, Yang Y, Wei Q, Wen L, and $\mathrm{He}$ Z. Zearalenone induces apoptosis and necrosis in porcine granulosa cells via a caspase-3-and caspase-9-dependent mitochondrial signaling pathway. J Cell Physiol. 2012;227(5):18141820

16. Kumar V, Cotran RS and Robins S. Basic Pathology. $7^{\text {th }}$ Ed. Saunders Philadelphia. Alihbahasa. Jakarta: EGC; 2005.

17. Guerrero AD, Schmitz I, Chen M, Wang J. Promotion of caspase activation by caspase 9 mediated feedback amplification of mitochondrial damage. Department of Pathology and Immunology. Baylor College of Medicine. Houston, Texas, USA. J Clin Cell Immunol. 2012;3:3.

18. Ji-Yeon Y, Zheng ZH, Son YO, Shi X, Jang YO, Lee JC. Mycotoxin zearalenone induces AIF- and ROS-mediated cell death through p53and MAPK-dependent signaling pathways in RAW264.7 macrophages. J Tiv. 2011;25:1654-1663.

19. Doll S, Danicke S, Valenta H, Flachowsky G. In vitro studies on the evaluation of mycotoxin detoxifying agents for their efficacy on deoxynivalenol and zearalenone. Arch Anim Nutr. 2004;58:311-324. 